\title{
Effect of Short-Term Space Flight on Structure of Liver, Lungs, Bone and Bone Marrow of Japanese Quail Hatched on Orbital Station Mir
}

\author{
M. ZIBRÍN ${ }^{1}$, V. CIGÁNKOVÁ ${ }^{1}$, J. KOČIŠOVÁ ${ }^{1}$, E. TOMAJKOVÁ ${ }^{1}$, T. KOMOROVÁ ${ }^{2}$, \\ K. BODA ${ }^{3}$, P. WEISMANN ${ }^{4}$, O. A. DADASHEVA ${ }^{5}$, T. S. GURYEVA ${ }^{5}$ \\ ${ }^{1}$ University of Veterinary Medicine, Košice, Slovak Republic \\ ${ }^{2}$ Medical Faculty, University of P. J. Šafárik, Košice, Slovak Republic, \\ ${ }^{3}$ Research Institute of Veterinary Medicine, Ivanka pri Dunaji, Slovak Republic \\ ${ }^{4}$ Medical Faculty, Commenius University, Bratislava, Slovak Republic \\ ${ }^{5}$ Institute for Medical-Biological Problems, Moscow, Russia \\ Received September 19, 2003 \\ Accepted March 3, 2005
}

\begin{abstract}
Zibrín M., V. Cigánková, J. Kočišová, E. Tomajková, T. Komorová, K. Boda, P. Weismann, O. A. Dadasheva, T. S. Guryeva: Effect of Short-term Space Flight on Structure of Liver, Lungs, Bone and Bone Marrow of Japanese Quail Hatched on Orbital Station Mir. Acta Vet. Brno 2005, 74: 167-174.

The effect of hypergravity of launch, microgravity during short-term space flight, and hypergravity of landing on the structure of liver, lung, bone and bone marrow of 3 Japanese quail, that hatched on board the orbital station Mir was investigated. Chicks were 5 days old at landing. Eleven hours after landing 3 male chicks were killed and samples were collected for a wide variety of biochemical, histological, histochemical, electron microscopic and microbiological investigations. Results of the light microscopic, and transmission electron microscopic study are presented in this paper. Extensive deposits of fat droplets were revealed in almost all hepatocytes of all flight chicks versus ground and laboratory controls. Adipocytes, common in the bone marrow of control animals of the same age, were depleted or absent in bone marrow of flight chicks. There were no substantial effects on the structure/ultrastructure of the lungs, the structure of the bone and its development was not substantially affected. Morphometry of the liver revealed that hepatocytes contained significantly more lipid droplets (nearly 5-fold) than hepatocytes of ground control chicks of the same age hatched at the same time. Morphometric study of lungs revealed no significant difference in number, diameter and total surface of air capillaries between flight and control chicks of the same age.

We propose that structural changes in the liver and bone marrow were not caused by direct effect of microgravity per se, but most probably resulted from an insufficient intake of feed due to stress of the microgravity environment and the resulting delay in uptake of lipids from liver. We suppose that these structural changes are the tissue and cellular response to microgravity and they are consistent with literature data known as "space adaptation syndrome".
\end{abstract}

Japanese quails, space flight, effect of microgravity, light and electron microscopy

Ability of humans to be sustained in space, whether in orbital space labs and stations or during future long-distance space missions requires supplementing the astronauts' diet. Birds appear to be the most effective converters of plant biomass to animal proteins in an closed system. Among birds, the Japanese quail is considered the most advantageous for spaceflight travel as it has very high rate of reproduction and in relation to its body weight the Japanese quail produces 2.5 times more egg biomass than the domesticated chicken. The orbital station or spacecraft constitute an artificial closed ecosystem operating near 0-G (in weightlessness or microgravity) conditions (B od'a 1993). Accordingly, it is necessary to know in detail the life cycle of Japanese quail, particularly stages sensitive to microgravity or weightlessness, i.e., the production of gametes, fertilization, critical stages of embryogenesis, hatching, early post-incubation development, growth, and maturation. The aim of this study was to investigate the effect of microgravity during brief space flight on

Address for correspondence:

Prof. MVDr. Martin Zibrín, PhD.

Department of Anatomy, Histology and Physiology

University of Veterinary Medicine

Komenského 73,041 81 Košice, Slovakia
Phone: +421556325844

Fax: +421 556323666

E-mail: zibrin@uvm.sk

http://www.vfu.cz/acta-vet/actavet.htm 
the development and structure of selected tissues and organs and to re-evaluate our preliminary results of investigation on structure of liver and lungs from this experiment (Zibrín et al. 2001). Since lipid droplets accumulate in the hepatocytes of chick embryo (Noble and Moore 1967) culminating on the first day of life of chicken (Baranyiova and Holman 1972), we used morphometric methods to evaluate the deposits of lipids in liver cells to distinguish whether the accumulation of lipid droplets of the Japanese quail hatched in the orbital station (Zibrín et al. 2001) was physiological or whether it was the effect of space flight. We tested our hypothesis that there would be stress-related changes in the liver of flight chicks versus ground controls.

\section{Materials and Methods}

Animals

Japanese quail (Coturnix coturnix japonica) eggs were first incubated on Earth. Shortly before launching, the eggs in an incubator were transferred to the spacecraft Soyuz that transported them to the orbital space lab Mir. At the time of launch the spacecraft, the eggs were in an advanced stage of incubation, about 2 - 3 days prior to hatching. 36 quails hatched of 60 incubated eggs and were taken care of by a Slovak astronaut, Colonel Ing. Ivan Bella (Plate I, Fig. 1). The chicks were 5 days old upon landing. Eleven hours after landing, a large number of samples from different organs of 3 alive male Japanese quails 5 days old were taken for histological, electronmicroscopical, histochemical and many other investigations. Male Japanese quails of the same age, hatched on Earth at the same time as experimental chicks in the orbital station, were used as "synchronous" Moscow controls. Another 5 chicks of the same sex and age incubated and hatched in Košice in October 2001 fed the same diet as experimental "flight"chicks in the orbital station, were used as "asynchronous" control Košice.

Light microscopy (LM)

We examined haematoxylin and eosin stained $5-7 \mu \mathrm{m}$ paraffin sections cut from organs fixed in $4 \%$ neutral formaldehyde and routinely processed, and toluidine blue stained $1 \mu \mathrm{m}$ Durcupan sections from specimens processed for electron microscopy. Fixed bones were decalcified in EDTA and processed routinely as above.

Transmission electron microscopy (TEM)

The material was immediately fixed in 3\% glutaraldehyde in $0.15 \mathrm{M}$ cacodylate buffer $\mathrm{pH} 7.2$ for 2 hours. Fixed specimens were rinsed in the $0.15 \mathrm{M}$ cacodylate buffer overnight, post-fixed in $1 \% \mathrm{OsO}_{4}$ in the same buffer, rapidly dehydrated in acetone and embedded in Durcupan ACM. Ultrathin sections stained with uranyl acetate and lead citrate were photographed by either the Tesla BS 500 or JEM 1200 EX electron microscope.

\section{Morphometric evaluation}

Three different methods were used for morphometric study of hepatocytes: manual measurement, semiautomatic evaluation by computer and fully automatic system analySIS (Soft Imaging System) GmbH, Munster, Germany. All measurements were taken from light micrographs of $1 \mu \mathrm{m}$ Durcupan sections stained by toluidine blue, all micrographs taken at the same magnification $\times 600$. Semi-automatic measurement was done by manual recording using a computer (by clicking and labelling of lipid droplets of three size categories on the computer screen) from scanned area of the same size $140.35 \mu \mathrm{m} \times 105.26 \mu \mathrm{m}$ of light micrographs. Three measurements of each of three micrographs were done, at least two tissue blocks were cut from each liver and three different micrographs from different $1 \mu \mathrm{m}$ Durcupan sections were taken from each tissue block. Fully automatic morphometrical measurements were done after shading correction. All measured objects were separated by observer controlled thresholding. Delesse's principle "area density = volume density" (Polónyi 1988; Royet 1991; White et al. 1999) was used in morphometric evaluation of liver and lungs. Morphometric analysis of lungs employed these criteria: (1) number of small, medium and large air capillaries in a given area of lungs of experimental and control quails; (2) diameters of air capillaries; and (3) total surface of air capillaries (i.e. the total area of gaseous exchange calculated for one pulmonary lobule) for flight versus control chicks.

Statistical analysis

The mean morphometric values of the liver and lungs of experimental flight and control chicks were compared by Student's $t$-test. The data presented in a graph and tables are average values of measurements according to the previous section.

\section{Results}

This paper presents the results of our study of bone, cartilage and bone marrow, liver and lungs. Significant structural changes were found in the liver and bone marrow. LM revealed an increase of lipids the liver, and demonstrated lipid droplets in most hepatocytes (Plate I, Fig. 2) of all three quail hatched on spacelab Mir and returned live to Earth. Only a few fat 
droplets were seen in hepatocytes of both synchronous (Plate I, Fig. 3) and asynchronous control chicks. TEM confirmed the LM results on fat deposits in hepatocytes of flight chicks (Plate II, Fig. 4) versus depletion of lipid droplets in hepatocytes of control chicks (Fig. 5). TEM also revealed that the ultrastructure of hepatocytes was well preserved; the organelles (nucleus, mitochondria, rough and smooth endoplasmic reticulum, Golgi bodies, and lysosomes) of hepatocytes in flight chicks were similar to those in control animals. Large or medium size fat droplets were located between the cell nucleus and the bile pole of hepatocytes, and small lipid droplets occurred randomly in the cytoplasm of liver cells. We evaluated the amount the fat deposits and the size of lipid droplets in liver cells by three different morphometric methods: manual, computer semiautomatic and the modified analySIS (Soft Imaging System). Each of them showed the overall amount of lipid droplets in the liver of all investigated flight chicks significantly higher than in the control birds of the same age incubated and hatched on the Earth (Tables $1-3$ and Graph 1).

Table 1. Morphometry of lipid droplets in hepatocytes of Japanese quails by 3 different methods. Numbers are mean values of all measurements by particular morphometric method. Total area is the total area of lipid droplets in measured area of liver; different in each morphometric method.

\begin{tabular}{|l|c|c|c|c|c|c|}
\hline \multirow{2}{*}{} & \multicolumn{2}{|c|}{ Manual } & \multicolumn{2}{c|}{ Semiautomatic } & \multicolumn{2}{c|}{ AnalySIS system } \\
\cline { 2 - 7 } & \multicolumn{2}{|c|}{ Total area } & \multicolumn{2}{c|}{ Total area } & \multicolumn{2}{c|}{ Total area } \\
& $\mu \mathrm{m}$ & $\%$ & $\mu \mathrm{m}$ & \multicolumn{1}{c|}{$\%$} & $\mu \mathrm{m}$ & $\%$ \\
\hline flight 3 & $2,990.14$ & 29.90 & $3,152.44$ & 21.33 & $10,962.41$ & 23.37 \\
\hline flight 4 & $4,103.46$ & 41.03 & $3,537.60$ & 23.94 & $12,346.32$ & 26.33 \\
\hline flight 5 & $2,982.74$ & 29.82 & $3,340.17$ & 22.60 & $11,272.23$ & 24.03 \\
\hline average 3-5 & $3,358.78$ & 33.58 & $3,343.40$ & 22.63 & $11,526.99$ & 23.68 \\
\hline control 1 & 363.81 & 3.63 & 458.02 & 3.10 & $1,372.50$ & 2.93 \\
\hline control 2 & 686.72 & 6.86 & 680.78 & 4.60 & $2,887.88$ & 6.15 \\
\hline average 1+2 & 525.26 & 5.24 & 569.40 & 3.85 & $2,130.19$ & 4.54 \\
\hline control Ke & 509.83 & 5.09 & 506.15 & 3.42 & $2,445.61$ & 5.21 \\
\hline
\end{tabular}

Table 2. Size of lipid droplets in the hepatocytes of Japanese quails (MV $\pm \mathrm{SEM})$

\begin{tabular}{|l|c|c|c|}
\hline & \multicolumn{3}{|c|}{ Lipid droplets in hepatocytes (in $\mu \mathrm{m})$} \\
large & $\varnothing \begin{array}{l}\text { mium } \\
\text { small }\end{array}$ \\
\hline flight & $\varnothing 5.98(8.4-4.9)$ & $\emptyset 3.69(4.9-3.2)$ & $\emptyset 1.32(1.7-0.9)$ \\
\hline control & $\varnothing 5.58(6.5-4.9)$ & $\varnothing 3.93(4.4-3.5)$ & $\varnothing 1.42(1.8-0.9)$ \\
\hline
\end{tabular}

Table 3. Amount of lipid droplets in the hepatocytes of Japanese quails measured by semiautomatic method $(\mathrm{MV} \pm \mathrm{SEM})$

\begin{tabular}{|l|c|r|r|r|r|c|}
\hline & No. of nuclei & \multicolumn{3}{|c|}{ Number of lipid droplets } & Total volume & Volume \\
of hepatocytes & \multicolumn{1}{|c|}{ large } & \multicolumn{1}{c|}{ medium } & \multicolumn{1}{c|}{ in $^{3}$} & in $\%$ \\
\hline flight 3 & 87.2 & $44.6 \pm 2.0$ & $143.8 \pm 3.8$ & $107.5 \pm 18.0$ & $1,165,802.7$ & 56.22 \\
\hline flight 4 & 89.5 & $45.0 \pm 2.6$ & $191.2 \pm 8.2$ & $179.5 \pm 22.2$ & $1,216,706.5$ & 58.00 \\
\hline flight 5 & 97.0 & $47.6 \pm 2.6$ & $165.6 \pm 7.6$ & $179.2 \pm 18.8$ & $1,007,297.5$ & 48.05 \\
\hline control 1 & 82.6 & $7.6 \pm 0.6$ & $46.3 \pm 0.4$ & $100.7 \pm 0.6$ & $88,647.2$ & 4.37 \\
\hline control 2 & 109.7 & $8.7 \pm 1.2$ & $33.5 \pm 0.6$ & $81.7 \pm 1.2$ & $52,695.1$ & 2.54 \\
\hline
\end{tabular}

Similar, but less dramatic effects were demonstrated in the bone marrow. Adipocytes were reduced (Plate II, Fig. 6 ) or absent from the bone marrow of flight quail if compared with control chicks (Fig. 7 ). Many fat cells are regularly present in the bone marrow of control Japanese quail chicks of the same age. This could be well detected even by LM in paraffin (Fig. 7 ) as well as $1 \mu \mathrm{m}$ Durcupan sections in all control Japanese quail chicks under study. 


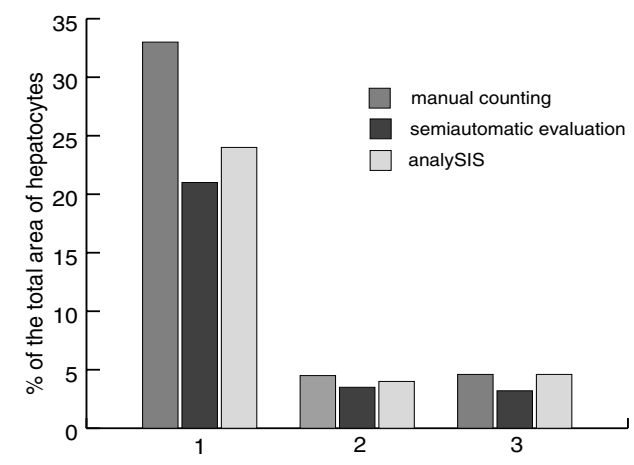

Graph 1. The occurrence of lipid droplets in liver of Japanese quail obtained by 3 different morphometric methods in: 1 - flight chicks after return from space; 2 - synchronous control (Moscow); 3 - asynchronous control (Košice)

Neither compact bone (Fig. 6) nor hyaline cartilage of the developing bones nor the lungs (Plate III, Fig. 8) showed any obvious change when observed by LM or TEM. We did not find by LM any important difference between lungs of control and experimental chicks hatched in the orbital station. Both parabronchi and atria (Fig. 8) and the air capillaries (Fig. 9) seemed not to be affected by space flight. Very rarely some erythrocytes were found inside air capillaries (Fig. 10). TEM revealed accumulation of erythrocytes in blood capillaries around air capillaries of flight chicks (Plate IV, Fig. 11) if compared with controls (Fig. 12). The majority of the air capillaries were regular round or mild oval in cross section both in control and flight chicks (Figs. 11 - 13). Some air capillaries showed irregular shape, a few being collapsed (Fig. 14). To take into account all minor ultrastructural deviations we used morphometric analysis of lungs at the level of LM. A detailed presentation of morphometric evaluation of lungs is in Tables 3 and 4 . This analysis revealed no significant difference $(p<0.05)$ between lungs of control and flight chicks (Tables 4 and 5). Significantly, the overall area of gas exchange was increased by 1.23 fold $(23.5 \%)$ in flight chicks. The number and diameter of air capillaries did not change significantly except for the infundibulum, which occurred in experimental flight chicks twice as much as in control.

Tables 4 and 5 Morphometry of lungs

Table 4. Some morphometric values of air capillaries of Japanese quail chicks (MV \pm SEM)

\begin{tabular}{|l|c|c|c|c|c|}
\hline & \multicolumn{3}{|c|}{$\begin{array}{c}\text { Number of air capillaries } \\
\text { medium }\end{array}$} & $\begin{array}{c}\text { Total area of cross cut } \\
\text { air capillaries in } \mu \mathrm{m}^{2}\end{array}$ & $\begin{array}{c}\text { \% of measured } \\
\text { area of lungs }\end{array}$ \\
\hline flight 3 & $7.6 \pm 0.12$ & $19.8 \pm 2.7$ & $39.8 \pm 2.1$ & $2,380.43$ & 16.1 \\
\hline flight 4 & $8.0 \pm 0.12$ & $19.6 \pm 2.7$ & $35.2 \pm 2.1$ & $2,424.66$ & 16.4 \\
\hline flight 5 & $7.7 \pm 0.12$ & $11.4 \pm 2.7$ & $42.2 \pm 2.1$ & $2,060.88$ & 13.9 \\
\hline control 1 & $3.8 \pm 0.07$ & $13.6 \pm 0.4$ & $41.8 \pm 2.4$ & $1,821.61$ & 12.3 \\
\hline control 2 & $3.8 \pm 0.07$ & $12.4 \pm 0.4$ & $50.0 \pm 2.4$ & $1,886.15$ & 12.7 \\
\hline
\end{tabular}

Table 5. Size of air capillaries in the lungs of Japanese quail chick (MV \pm SEM)

\begin{tabular}{|l|c|c|c|}
\hline & \multicolumn{3}{|c|}{ Diameter of air capillaries in $\mu \mathrm{m}$} \\
medium & small \\
\hline flight & $\varnothing 13.0(13.7-10.0)$ & $\varnothing 7.4(8.1-6.2)$ & $\varnothing 4.1(4.7-3.1)$ \\
\hline control & $\varnothing 12.6(15.9-10.8)$ & $\varnothing 8.2(9.2-7.3)$ & $\varnothing 4.4(5.4-3.3)$ \\
\hline
\end{tabular}




\section{Discussion}

The effect of weightlessness and microgravity on structure and function of different tissues and organs of various animals, particularly in the rat and Japanese quail has been studied by a number of authors (e.g. Vico et al. 1987, 1988; Dadasheva and Guryeva 1993; Kawashima et al. 1995; Anderson et al. 1997; Barrett et al. 2000; Y amashita et al. 2001; Rodionova et al. 2002; Krasnov and Diachkova 2003). Embryogenesis and development of both quail and chicken exposed to microgravity was studied by Guryeva et al. 1993; Hullinger 1993; Suda et. al. 1994; Dadasheva and Shepelev 1996; Suda 1998 and others.

Essentially, there are serious problems with early development of quail and chicken in microgravity conditions. These include a high percentage of dead embryos and numerous severe developmental organ anomalies (reviewed by Dadasheva and Shepelev 1996) and other less obvious deficits, such as the detrimental effect of microgravity on vestibular system (Fermin et. al. 1996). The mechanism for the genesis of these developmental problems remains unknown. Nevertheless, some systems seemingly remain unperturbed. Suda (1998) reported in chickens that "the development of all tissues including the cartilage and bone tissue was normal in 7- and 10-day-old chicks". For chicken embryos that enter the microgravity after completing early development in $1-G$, there was no ill effect of spending a 5 days in orbit at near 0-G. After returning to Earth, the subsequent incubation and hatching was also normal (Hullinger 1993; Suda 1998). Unlike mammals (e.g. Vico et al. 1987; Ilyin and Oganov 1989; Rodionova et al. 2002), microgravity has little effect on growth and development of chick embryonic bone (K a w a shima et al. 1995). This is in agreement with our observation. LM of the bone and cartilage of Japanese quail chicks hatched in the orbital station showed no adverse effects due to microgravity after a shortterm space flight lasting 5 days. Development of bones in flight chicks was not different than that observed in control chicks of Japanese quail of the same age (Marettová et al. 1992).

There was little adverse effect of space flight on the lungs in this study. Avian lungs have air capillaries instead of alveoli as in mammals; granular pneumocytes (the type II pneumocytes) and dust cells - (macrophages) are not present at the site of gaseous exchange in the air capillaries but both granular cells and macrophages are found at the level of conductive portion of lungs (Abdalla et al. 1982; Klika et al. 1996; Scheuermann et al. 1997). Taking into account these structural and functional characteristics of avian lung (Abdalla et al. 1982; Maina 1988; Klika et al. 1999; Bernhard et al. 2001), substantial no differences in the structure/ultrastructure of lungs between experimental and control chicks were found by LM and TEM in this experiment. Morphometry of the lungs revealed no significant difference between the lungs of control and flight chicks. We assume that erythrocytes present in air capillaries of the flight chicks were the result of local venostasis in lungs or more probably they could be artifacts.

The most striking effect of microgravity on Japanese quails hatched in MIR was the massive lipidosis in the vast majority of hepatocytes in all 3 flight chicks. There is a physiological accumulation of lipid droplets in the liver of birds (Noble and Moore 1967), starting on day 19 of incubation for chicken embryos and culminates 1 day after hatching. Thereafter the number of lipid droplets in hepatocytes of 3-day-old chicks begins gradually to decrease (Baranyiová and Holman 1972). In hepatocytes of 10-day-old chicks lipid droplets are rare. Considering this physiological accumulation of lipids in the liver of the birds near the end of embryonic development and their persistence in the initial days after hatching, it was necessary to evaluate our preliminary observations on the liver of flight chicks of Japanese quail by a reliable and objective method. Each of the three different morphometric methods (manual, computer semiautomatic and the analySIS (Soft Imaging System) used in this study showed the overall amount of lipid droplets in the liver 
of all investigated flight chicks was 5-fold greater than in control birds of the same age, incubated and hatched as ground controls.

These observations of tissue from the Japanese quails chicks hatched in microgravity are original and we are aware of no published data for comparison. The occurrence of lipid droplets in the liver cells is histologically similar to syndrome of fatty liver (FLS - fatty liver syndrome, now called lipidosis by the pathologist) in chicken (Bain 1977; L onkar and Pras ad 1988). Excessive accumulation of lipids in the liver is usually related to different systemic metabolic conditions and also liver diseases (Jubb et al. 1991; Cheville 1994; Cotran et al. 1994). The most frequent of these is hepatocellular damage induced by poisons or drugs, insufficient movement and stress, or excessive intake of energy-rich food with high protein content. Starvation also leads to FLS in birds and mammals. B a in (1977) reported large accumulations of fat in the hepatocytes of 4-week-old chickens as a result of stress by removal of food.

The accumulation of lipid droplets in the liver of quail chicks hatched aboard spacelab MIR and living there for 5 days under microgravity conditions, is difficult to interpret unambiguously. A structural resemblance to FLS is obvious. The accumulation of fat in the liver of flight quail chicks could be caused by an insufficient intake of feed due to microgravity. This unintended "fasting" of animals would then be followed by mobilization of energy reserves of the body and lipolysis from fatty tissues. Fat cells common in bone marrow of young chick, had disappeared from the bone marrow of flight quails. Our interpretation of fatty liver in flight chicks followed a conversation with Col. Ing. Ivan Bella, the Slovak astronaut who was the mission specialist for this space experiment. He made an enormous effort, together with the two other two members of the crew to keep all the hatched quails alive, hand-feeding and watering them by pipette (Plate I, Fig. 1). Due to the lack of gravity in the space lab, and the resulting effect upon the quail feeding behaviour the intake of food was restricted. Len hardt et al. (2001) found slightly increased alkaline phosphatase activity in the microvilli of the enterocytes of the same quails suggesting an adaptation to utilize the restricted feed stuffs more efficiently. We suppose that the insufficient feed intake caused a mobilization of fat reserves in the body and accumulation of lipids in the liver. Fasting results in mobilization of lipid stores shortly after hatching (Baranyiová and Standara 1980). This mobilization of lipids also resulted in a depletion of adipocytes in the bone marrow of all 3 flight chicks in this experiment. Our interpretation is also supported by observations Mišúrová et. al. (1990) who found hyperlipaemia and hyperglycaemia caused by the lipolysis of adipose tissue in rats flown aboard Cosmos 2044. However, another explanation of the accumulation of lipids in liver is also possible. According to Feast et al. (1998), lipid uptake from the liver was significantly reduced if chick embryo is exposed to $22.0^{\circ} \mathrm{C}$. From this perspective the accumulation of lipids in hepatocytes of flight chicks may have result from a delayed lipid uptake from the liver of chicks living in microgravity and/or due to adverse (stressful) conditions in the space lab.

Nevertheless, whatever is the origin of lipid droplets occurring in most hepatocytes of all flight chicks we conclude that the launch of the space shuttle, the short-term space flight in the orbital station under microgravity conditions and the landing on Earth had no substantial effect on the structure of tissues and organs investigated from three Japanese quail chicks. We further conclude that the structural changes in the liver and bone marrow are not a direct cause of microgravity but are instead a secondary consequence of microgravity. We suppose that these changes would be reversible.

\section{Vplyv krátkodobého pobytu v kozme na štruktúru niektorých tkanív a orgánov japonských prepelíc, vyliahnutých na palube orbitálnej stanice Mir}

Študovali sme vplyv krátkodobého pobytu v kozme na štruktúru niektorých orgánov a tkanív 3 kurčiat japonských prepelíc, ktoré sa vyliahli na orbitálnej stanici Mir a na 7. deň 
kozmického letu sa živé vrátili na Zem. V čase pristátia kurčatá mali 5 dní. Vzorky pre svetelnú (LM) a transmisnú elektrónovú mikroskopiu (TEM) boli odobraté z 3 živých kurčiat kohútikov po návrate na Zem. V práci prezentujeme výsledky štúdia štruktúry pečene, plúc, kostí vrátane kĺbovej chrupky a kostnej drene. V pečeni všetkých troch letových kurčiat sme pozorovali tukové kvapky takmer vo všetkých hepatocytoch. Z kostnej drene letových kurčiat čiastočne alebo úplne vymizli tukové bunky, na ktoré je bohatá kostná dreň kontrolných kurčiat. V práci prezentujeme výsledky troch spôsobov morfometrie tukových kvapiek $\mathrm{v}$ pečeni a morfometrie plúc. Z meraní vyplýva, že celkové množstvo tukových kvapiek $\mathrm{v}$ hepatocytoch pokusných prepelíc je asi 5 krát väčšie ako u kontrolných kurčiat rovnakého veku, ktoré sa v rovnakom čase vyliahli na Zemi. Morfometria plúc neodhalila medzi pokusnými a kontrolnými kurčatami signifikantné rozdiely v počte a priemere vzduchových kapilár a ich celkovej ploche. Naše pozorovania ukazujú, že krátkodobý pobyt vkozme nemá podstatný vplyv na štruktúru a vývoj kostí a ultraštruktúru plúc. Predpokladáme, že zmeny vpečeni a kostnej dreni neboli spôsobené priamo mikrogravitáciou, ale jej sekundárnym účinkom ako dôsledok staženého príjmu potravy.

\section{Acknowledgements}

The project was a part of Slovak space research program Quail Sk supported by VEGA, the Grant Agency of Ministry of Education of the Slovak Republic Grant No. 1/0585/03. The authors are grateful to Prof. Jozef Maršala, DrSc. and RNDr. Nada Lukáčová, Neurobiological Institute, Košice and Prof. Jozef Beňuška, CSc., Medical Faculty UK Bratislava for use of their facilities for morphometric analysis. The authors wish to thank Mrs. Gertruda Greserová and Allan Taggart, British Council, Košice for language correction. The authors are very much grateful to Prof. Ronald L. Hullinger, Purdue University, West Lafayette, Indiana, USA, for his valuable comments on the manuscript.

\section{References}

ABDALLA, MA, MAINA, JN, KING, AS, KING, DZ, HENRY, J 1982: Morphometrics of the avian lung. 1. The domestic fowl (Gallus gallus variant domesticus). Resp Physiol 47: 267-78

ANDERSON, PAW, CONRAD, GW, BARRETT, JE, DOTY, SB, FERMIN, CD, FRITZSCH, B, BRUCE, LL, HESTER, PY, ORBAN, JI, LELKES, PI, UNSWORTH, BR, SHIMIZU, T, WENTWORTH, BC 1997: Mir 21/NASA 2 180-day report. Avian developmental biology flight experiments spacelab Mir-1 NASA research announcement NRA 93-OLMSA-06, pp. 1-30

BAIN, JM 1977: Biotin deficiency and the development of the fatty liver and kidney syndrome in chickens: an ultrastructural study. Aust J Biol Sci 30: 57-70

BARANYIOVÁ, E, HOLMAN, J 1972: Lipid droplets in hepatocytes of chicken embryos and chickens after hatching. Acta Vet Brno 41: 367-372

BARANYIOVÁ, E, STANDARA, S 1980: Effect of deutectomy, fasting and environmental temperature on free fatty acid concentration in the blood plasma of chickens in the first week after hatching. Acta Vet Brno 49: 187-192

BARRETT, JE, WELLS, DC, PAULSEN, AQ, CONRAD, GW 2000: Embryonic quail eye development in microgravity. J Appl Physiol 88: 1614-1422

BERNHARD, W, GEBERT, A, VIETEN, G, RAU, GA, HOHLFELD, JM, POSTLE, AD, FREIHORST, J 2001: Pulmonary surfactant in birds: coping with surface tension in a tubular lung. Amer J Physiol-Regul Integr C 281: R 327-337

BOD̃A, K 1993: The function of the heterotrophic efficiency organism as link of the food chain of the closed ecosystem in microgravity conditions. Acta Vet Brno 62, Suppl. 6: S91-S94

BOĎA, K, MELESHKO, GI, SABO, V, SHEPELEV, JJ, GURYEVA, TS, JURÁNI, M, KOŠŤA, L 1991: Embryonic development of Japanese quail under microgravity conditions. Physiologist 34, Suppl.: S59-S61

CHEVILLE, NE, 1994: Ultrastructural Pathology. Iowa State Press, Ames, 946 p.

COTRAN, RS, KUMAR, V, ROBBINS, SL 1994: Robbins Pathologic Basis of Disease.W.B.Saunders Co, Philadelphia, $1400 \mathrm{p}$.

DADASHEVA, OA, GURYEVA, TS 1993: Bone and muscular tissue development in embryos and newly hatched quail incubated in weightlessness. Acta Vet Brno 62, Suppl. 6: S51-S60

DADASHEVA, OA, SHEPELEV, JJ 1996: Analysis of anomalies of quail embryonic development in egg during incubation in the conditions of space flight. Acta Vet Brno 65: S39-S42

FEAST, M, NOBLE, RC, SPEAKE, BK, FERGUSON, MW 1998: The effect of temporary reductions in incubation temperature on growth characteristics and lipid utilisation in the chick embryo. J Anat 193: 383-390

FERMIN, CD, MARTIN, D, JONES, T, VELLINGER, J, DEUSER, M, HESTER, P, HULLINGER, R 1996: Microgravity in the STS-29 space shuttle Discovery affected the vestibular system of chick embryos. Histol Histopathol 11: 407-426 
GURYEVA, TS, DADASHEVA, OA, MELESHKO, GI, SHEPELEV, JJ, BOĎA, K, SABO, V 1993: The quail embryonic development under the conditions of weightlessness. Acta Vet Brno 62, Suppl. 6: S25-S30

HULLINGER, RL 1993: Embryogenesis aboard shuttle STS-29. Acta Vet Brno 62, Suppl. 6: S17-S24

ILYIN, EA, OGANOV, VS 1989: Microgravity and musculoskeletal system of mammals. Adv Space Res 9: 11-19

JUBB, KVF, KENNEDY, PC, PALMER, N 1991: Pathology of Domestic Animals. Academic Press, San Diego, $4^{\text {th }}$ ed., Vol. 2, 747 p.

KAWASHIMA, K, YAMAGUCHI, A, SHINKI, T, NOJI, S, YOKOSE, S, YAMAAI, T, ENDO, H, YOSHIKI, S, ABE, E, SUDA, T 1995: Microgravity generated by space flight has little effect on the growth and development of chick embryonic bone. Biol Sci Space 9: 82-94

KLIKA, E, SCHEUERMANN, DW, De GROODT-LASSEEL, MH, BAZANTOVA, I, SWITKA, A 1996: Pulmonary macrophages in birds (barn owl, Tyto tyto alba), domestic fowl (Gallus gallus f. domestica), quail (Coturnix coturnix), and pigeons (Columba livia). Anat Rec 246: 87-97

KLIKA, E, SCHEUERMANN, DW, De GROODT-LASSEEL, MH, BAZANTOVA I, SWITKA, A 1999: A scanning and transmission electron microscopy study of the parabronchial unit in quail (Coturnix coturnix) and town pigeons (Columba livia). Scanning 21: 273-278

KRASNOV, IB, DIACHKOVA, LN 2003: Morphology of the rat brain in and after a space flight: ultrastructure of the blue spot (in Russian). Aviakosm Ekolog Med 37: 18-24

LENHARDT, L, CIGÁNKOVÁ, V, ZIBRÍN, M, KOČIŠOVÁ, J, TOMKOVÁ, I, SABO, V, BOĎA, K, DADASHEVA, OA, GURYEVA, TS, MOZEŠ, Š 2001: Functional development of small intestine of Japanese quail hatched on Mir orbital station. Acta Vet Brno 70: 127-131

LONKAR, PS, PRASAD, MC 1988: Fatty liver syndrome in chicken. Indian J Vet Pathol 12: 66-68

MAINA, JN 1988: Scanning electron microscope study of the spatial organization of the air and blood conducting components of the avian lung (Gallus gallus variant domesticus). Anat Rec 222: 145-153

MARETTOVÁ, E, DANKO, J, MARTINČEK, M 1992: The development of skeleton of the pelvic limb in Japanese quail. In: Abstracts of the Ninth European Anatomical Congress. Kraków, p. 162

MIŠÚROVÁ, E, AHLERS, I, AHLERSOVÁ, E, KROPÁČOVÁ, K 1990: Tissue chromatin, nucleic acids and lipids in rats flown aboard Cosmos 2044 biosatellite. In: Boda, K (Ed.): Current trends in cosmic biology and medicine. Vol. I: 319-324

NOBLE, RC, MORE, JH 1967: The liver phospholipids of the developing chick embryo. Can J Biochem 45: 627-641

POLÓNYI, J 1988: Electron micrographs evaluation. In: Mráz, P, Polónyi, J: Electron Microscopy Methods of Animal Tissues (in Slovak). Bratislava, Veda, p. 236

RODIONOVA, NV, OGANOV, VS, ZOLOTOVA, NV 2002: Ultrastructural changes in osteocytes in microgravity conditions. Adv Space Res 30: 765-770

ROYET, JP 1991: Stereology: a method of analyzing images. Prog Neurobiol 37: 433-474

SCHEUERMANN, DW, KLIKA, E, De GROODT-LASSEEL, MH, BAZANTOVA, I, SWITKA, A 1997: An electron microscopic study of the parabronchial epithelium in the mature lung of four bird species. Anat Rec 249: 213-225

SUDA, T 1998: Lesson from the space experiment sl-j/fmpt/17: the effect of microgravity on chicken embryogenesis and bone formation. Bone 22, Suppl. 5: S73 - S78

SUDA, T, ABE, E, SHINKI, T, KATAGIRI, T, YAMAGUSHI, A, YOKOSE, S, YOSHIKI, S, HORIKAWA, H, COHEN, GW, YASUGI, S, NAITO, M 1994: The role of gravity in chick embryogenesis. Febs Lett 340: 34-38

VICO, L, CHAPPARD, D, ALEXANDRE, C, PALLE, S, MINAIRE, P, RIFFAT, G, NOVIKOV, VE, BAKULIN, AV 1987: Effects of weightlessness on bone mass and osteoclast number in pregnant rats after a five-day spaceflight (COSMOS 1514). Bone 8: 95-103

VICO, L, CHAPPARD, D, PALLE, S, BAKULIN, AV, NOVIKOV, VE, ALEXANDRE, C 1988: Trabecular bone remodelling after seven days of weightlessness exposure (BIOCOSMOS 1667). Amer J Physiol 255: R 243-247

WHITE, SA, HUGHES, DP, CONTRACTOR, HH, LONDON, NJ 1999: A comparison of cross sectional surface area densities between adult and juvenile porcine islets of Langerhans. Hormone Metab Res 31: 519-524

YAMASHITA, M, IZUMI-KUROTANI, A, IMAMIZO, M, KOIKE, H, OKUNO, M, PFEIFFER, CJ, KOMAZAKI, S, SASASKI, F, OHIRA, Y, KASHIMA, I, KIKUYAMA, S, OHNISHI, T, MOGAMI, Y, ASASHIMA, M 2001: Japanese red-bellied newts in Space-AstroNewt experiment on Space Shuttle IML-2 and Space Flyer Unit. Biol Sci Space 15, Suppl.: S96-S103

ZIBRÍN, M, CIGÁNKOVÁ, V, KOČIŠOVÁ, J, TOMAJKOVÁ, E, KOMOROVÁ, T, LENHARDT, L, SABO, V, BODA, K, DADASHEVA, OA, GURYEVA, TS, 2001: The structure of some tissues and organs of Japanese quail hatched on the orbital space station "MIR". Folia Vet 45, Suppl.: S17-S22 


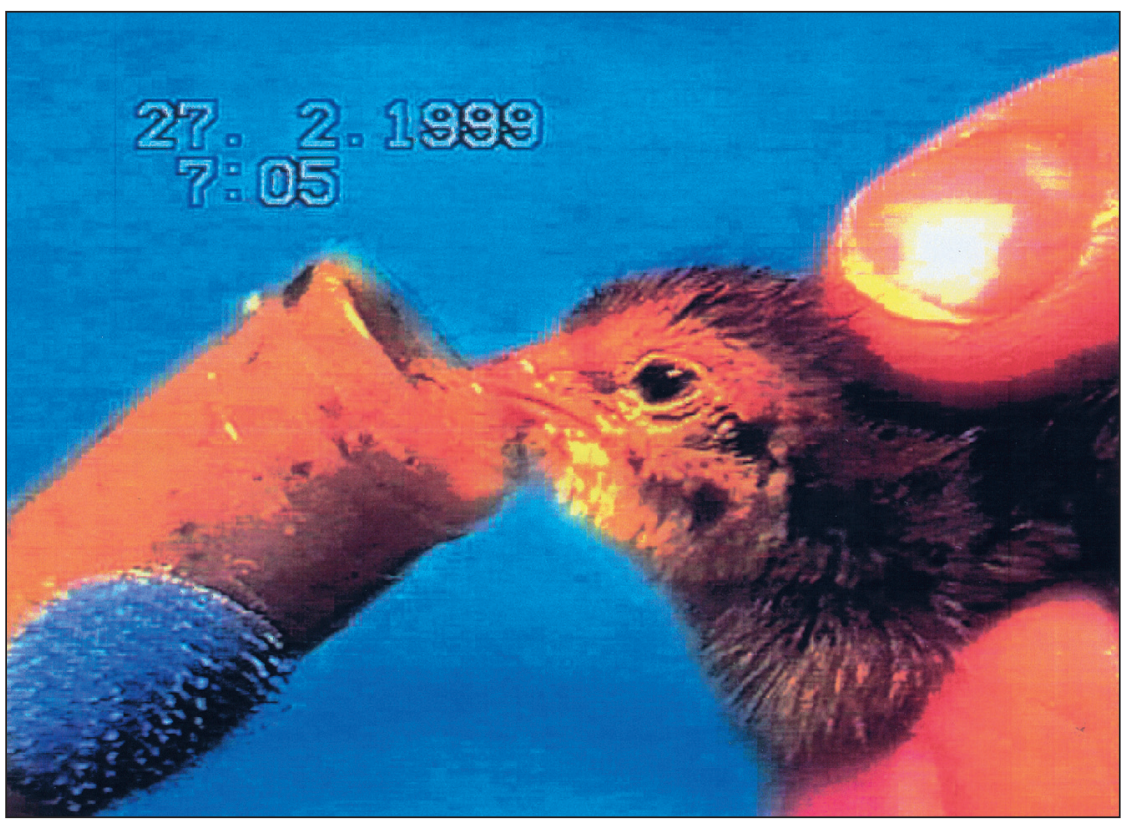

Fig. 1. Japanese quail chick fed by Slovak astronaut Col. Ing. Ivan Bella. Picture printed from the record in space lab MIR on February 27, 1999.

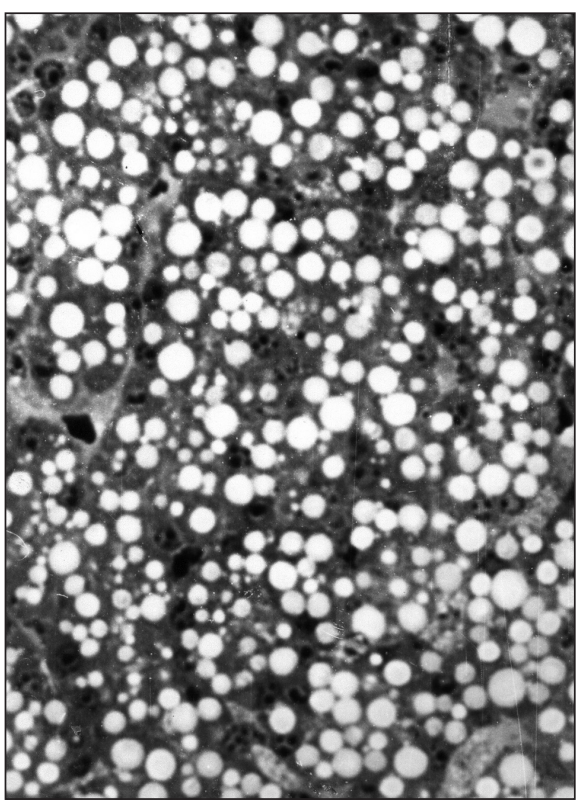

Fig. 2. Hepatocytes of a flight chick. Massive deposit of lipids in liver. Almost all hepatocytes contain lipid droplets. $1 \mu \mathrm{m}$ Durcupan section, toluidine blue, LM magnification $\times 600$.

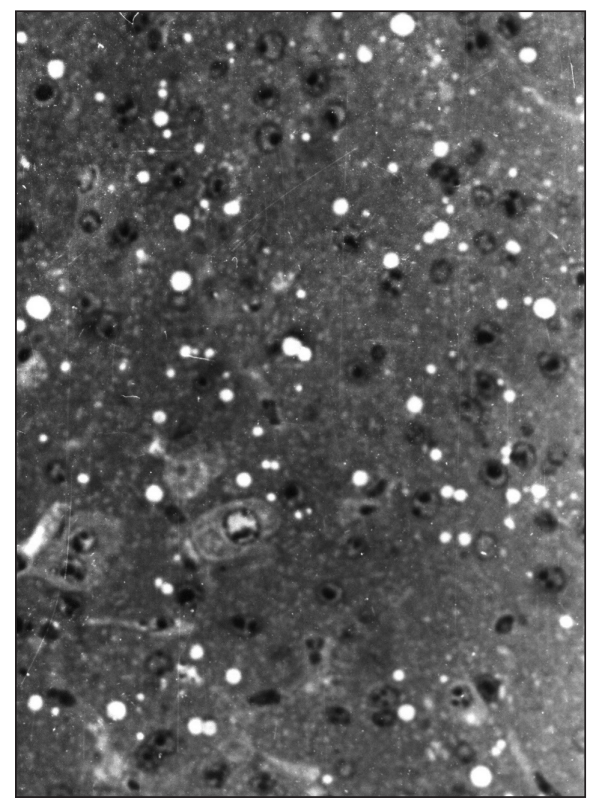

Fig. 3. Hepatocytes of a synchronous control chick. Lipid droplets occur sporadically. $1 \mu \mathrm{m}$ Durcupan section, toluidine blue, LM magnification $\times 600$. 


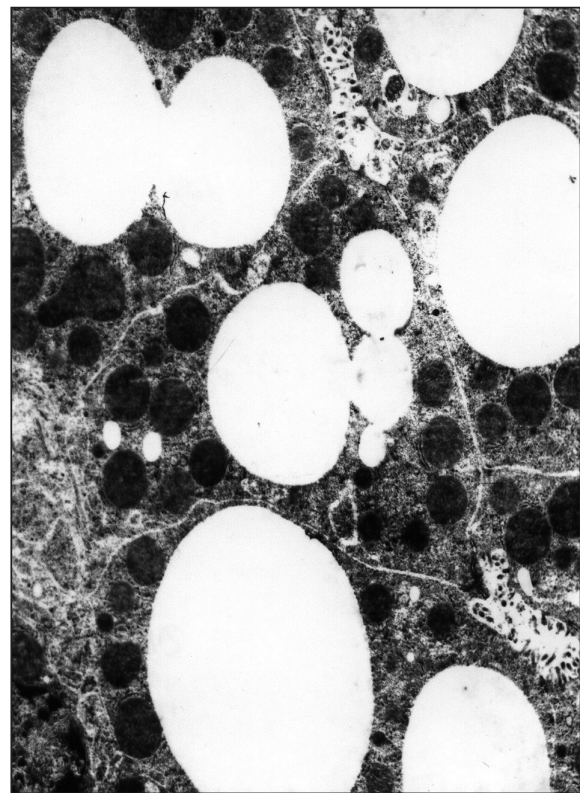

Fig. 4. Electron micrograph of liver of the same flight chick as in Fig. 2 shows numerous lipid droplets (L) and mitochondria (M) within hepatocytes. TEM magnification $\times 3,800$.

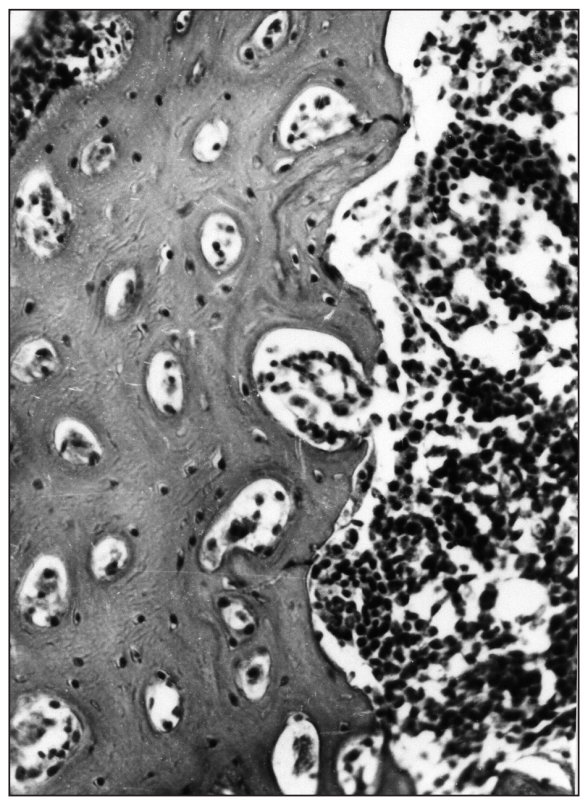

Fig. 6. Bone and bone marrow of a flight chick. No structural change in the compact bone is visible; a few fat cells are present in bone marrow. Paraffin section, $\mathrm{H}+\mathrm{E}, \mathrm{LM}$ magnification $\times 300$.

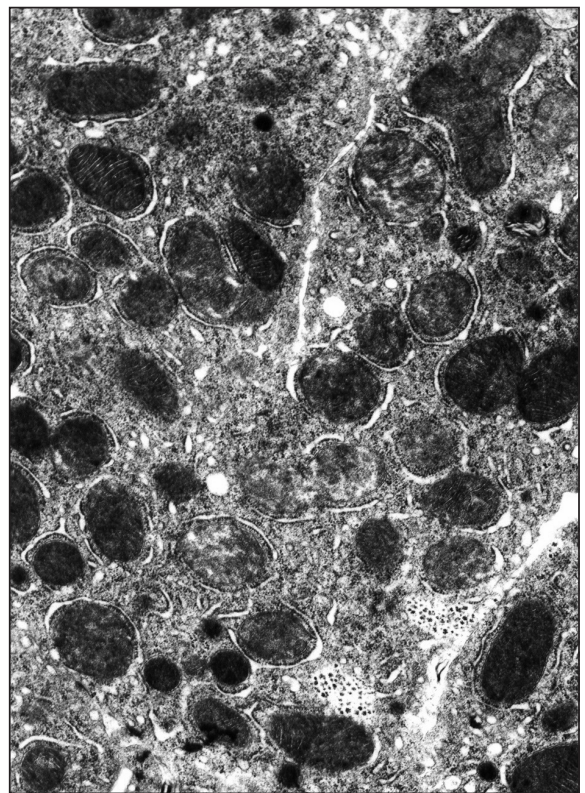

Fig. 5. Electron micrograph of liver of synchronous control chick. No large lipid droplets are present, only mitochondria, RER and SER are seen. TEM magnification $\times 6,200$.

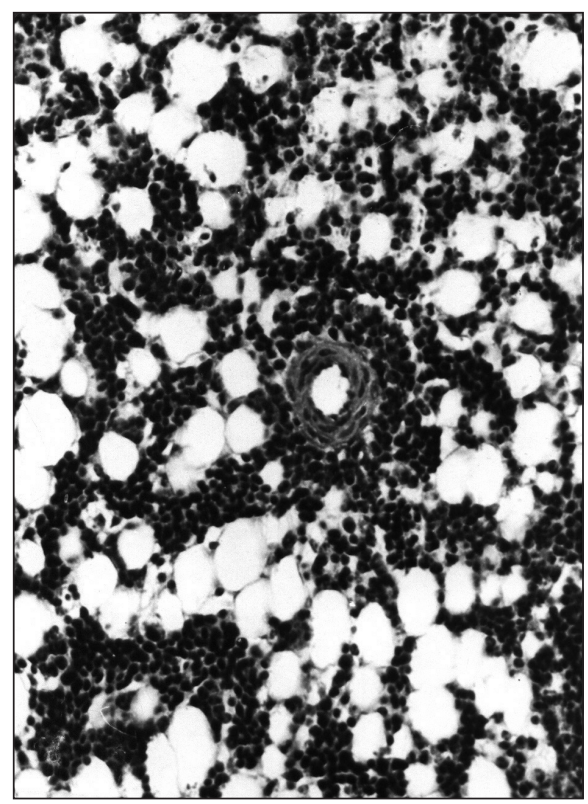

Fig. 7. Bone marrow of the synchronous control chick rich in adipocytes. Paraffin section, $\mathrm{H}+\mathrm{E}, \mathrm{LM}$ magnification $\times 300$. 


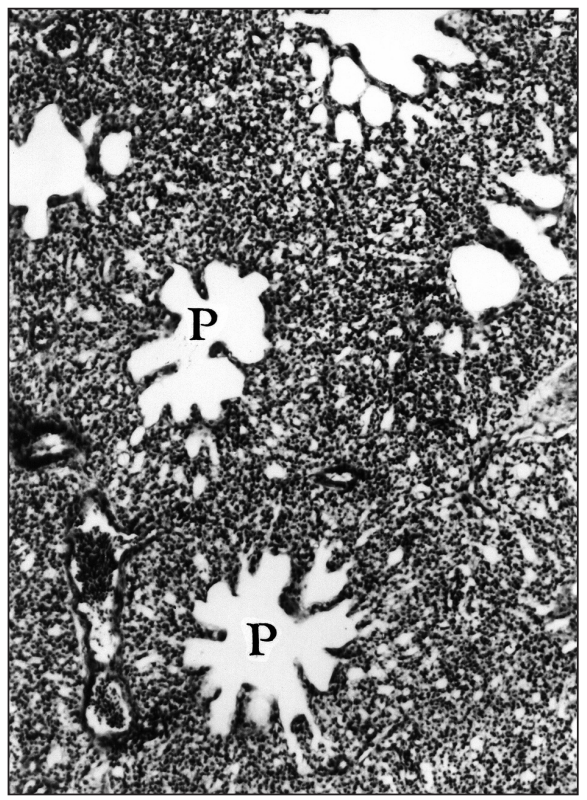

Fig. 8. The lungs of flight chick. Parabronchi (P), atria, infundibula and air capillaries show no structural changes under LM. Paraffin section, $\mathrm{H}+\mathrm{E}$, magnification $\times 150$.

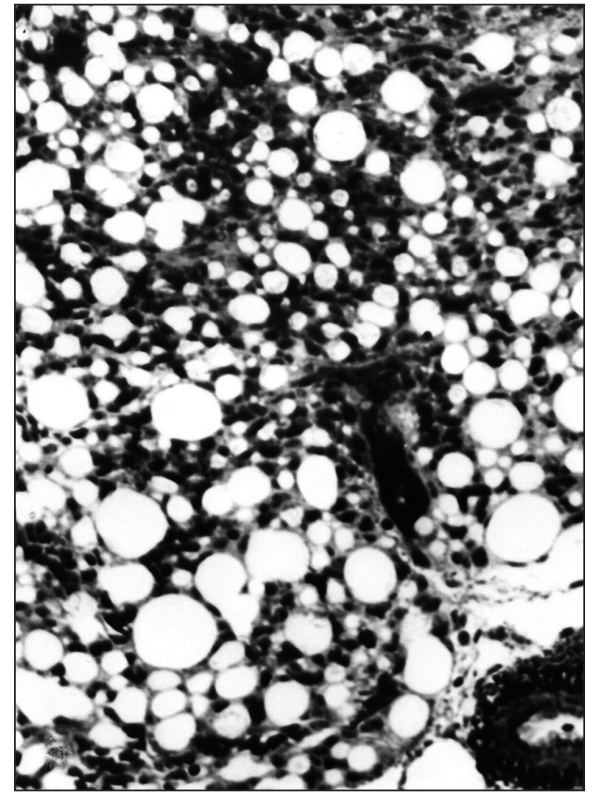

Fig. 9. The lungs of the same flight chick as in Fig. 8. Cross cut air capillaries of different size and diameter. $1 \mu \mathrm{m}$ thick Durcupan section, toluidine blue, LM magnification $\times 600$.

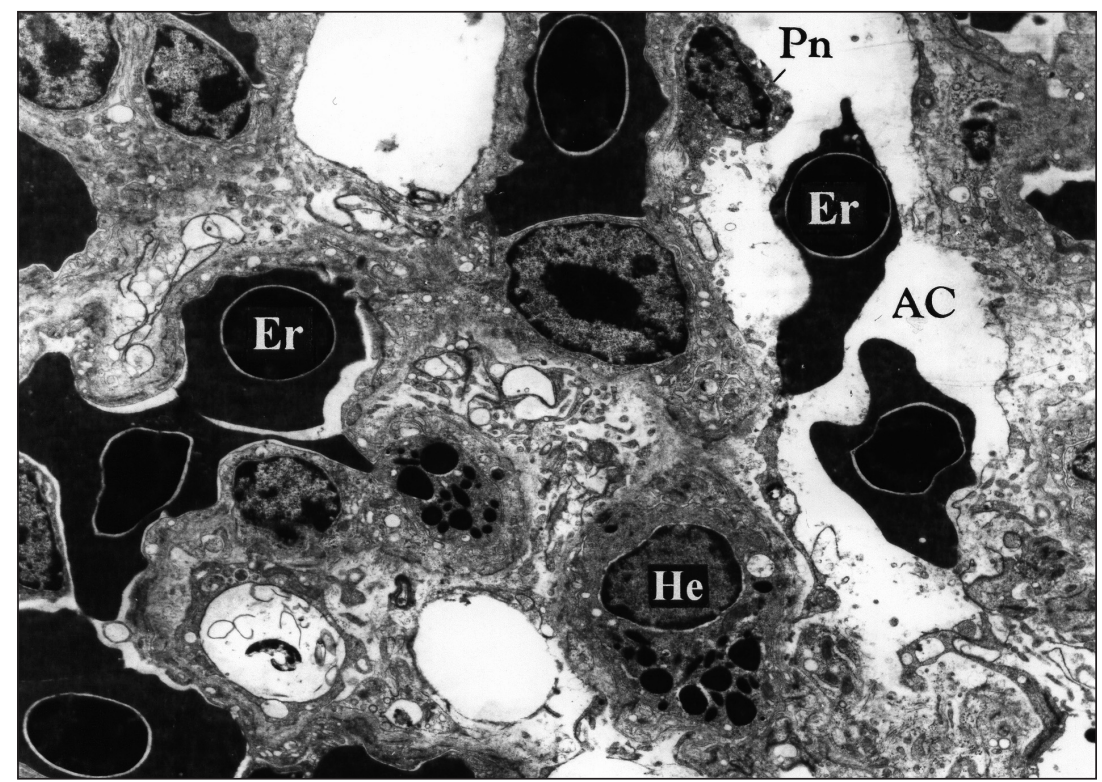

Fig. 10. The lungs of the same flight chick as in Fig. 8. Accumulation of erythrocytes (Er) in blood capillaries, a few erythrocytes (Er) in air capillary (AC) with pneumocyte (Pn); a lymphocyte, and two heterophils (He) in interstitium. TEM magnification $\times 7,200$. 


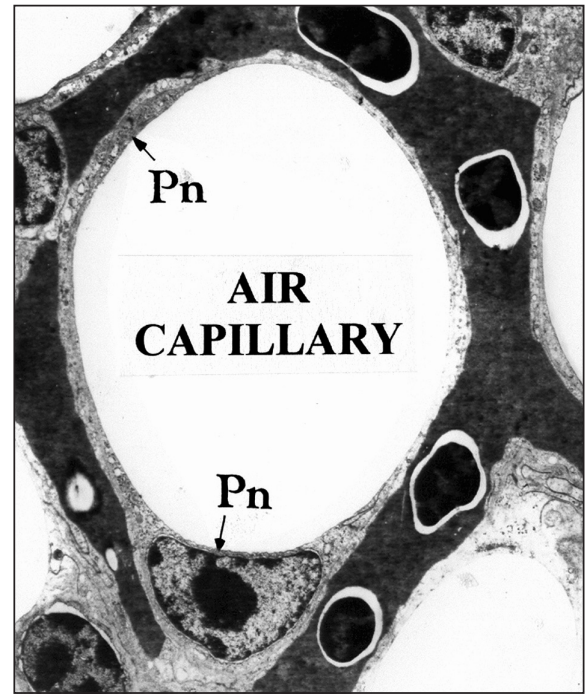

Fig. 11. Air capillary with pneumocyte $(\mathrm{Pn})$ in the lungs of flight chick. Erythrocytes around air capillary. TEM magnification $\times 7,200$.

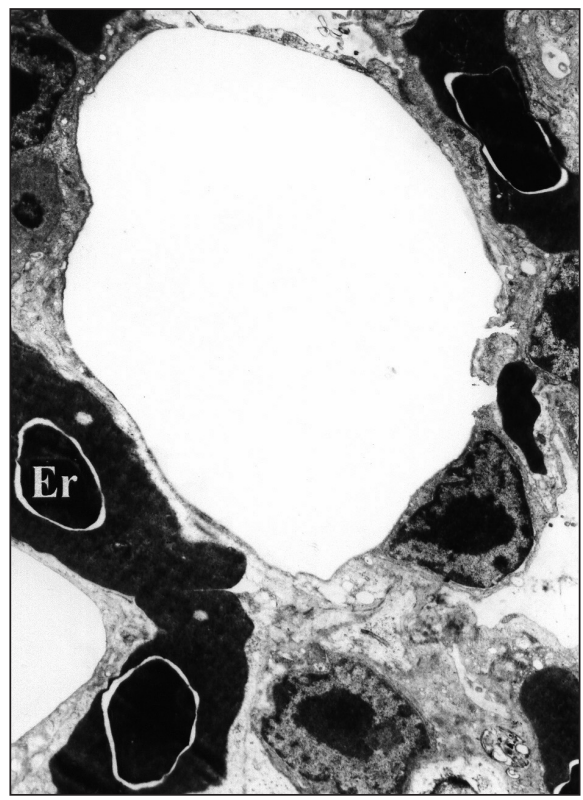

Fig. 13. Air capillary in the lung of another flight chick shows no distinct change. TEM magnification $\times 7,200$.

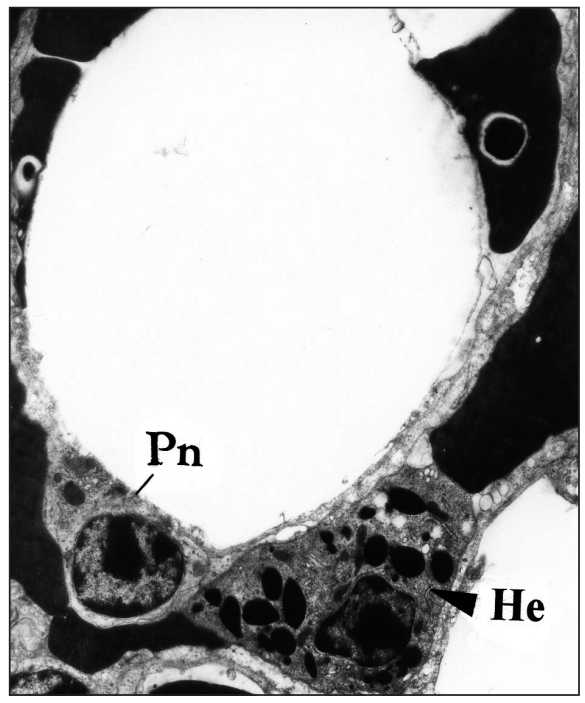

Fig. 12. Air capillary in the lungs of synchronous control chick of Japanese quail. Pneumocyte (Pn), and heterophil (He). TEM. magnification $\times 7,200$.

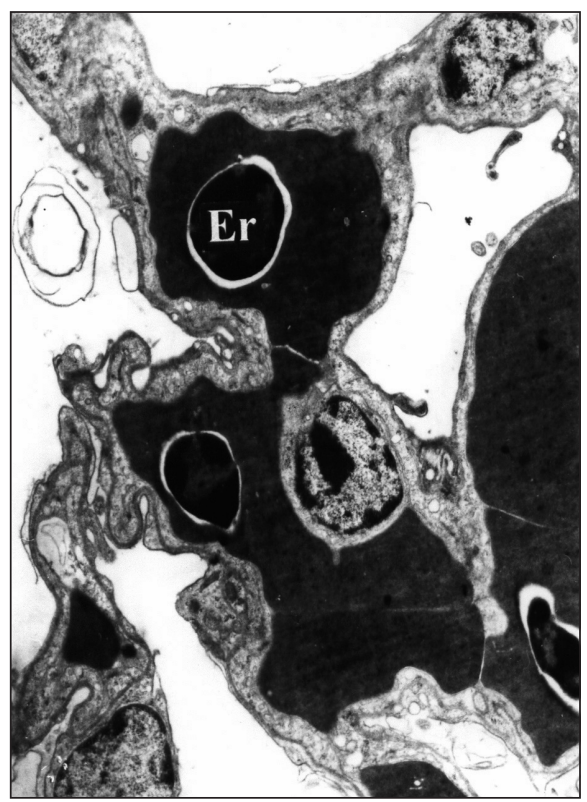

Fig. 14. Lungs of the same flight chick as in Fig. 8 . Some air capillaries show irregular shape, the others are more collapsed. TEM magnification $\times 7,200$. 